\title{
Molybdenum Cofactor Deficiency
}

\author{
William L Nyhan \\ Department of Pediatrics, University of California, USA
}

\section{Introduction}

Molybdenum cofactor deficiency causes deficiency of sulfite oxidase and xanthine oxidase. The latter leads to the formation of urinary tract calculi, as well as elevated concentrations of hypoxanthine and xanthine. The former leads to severe defiency of neurologic development and dislocated ocular lenses. Levels of sulfite, thiosulfite, sulfocysteine and taurine are elevated.

\section{Case Report}

R.M. was born after an uneventful pregnancy and delivery to a 26 year old primgravida. The parents were Caucasian and not consanguineous. Birth weight was $3455 \mathrm{~g}$. Apgar scores were excellent and physical examination was normal. Length was $51 \mathrm{~cm}$ and head circumference $39 \mathrm{~cm}$. The baby appeared well for 2 days, and then was noted to suck poorly; on examination, he was dusky, mottled and floppy. On immediate transfer to the NICU, he was apneic, $\mathrm{pH}$ was $7.08, \mathrm{pCO}_{2}$, 69 and $\mathrm{pO}_{2} 67$. He was intubated and ventilated mechanically. There were no tonic or clonic evidences of seizures, but the EEG, revealed status epilepticus. Ultrasound of the head suggested mild cerebral edema, but CT scan of the brain was interpreted as normal. He was treated with phenobarbital. EEGs 2, 4 and 7 days later revealed a burst suppression pattern.

Phenytoin treatment was added. MRI of the brain revealed $T_{2}$ hyperintensities in the cortex and globi pallidi, and subdural fluid was seen along the tentorium. MRI 10 days later revealed cerebral atrophy. MRI 7 months later revealed diffuse abnormal hyperintense $\mathrm{T}_{2}$ signal in the white matter bilaterally and diffuse atrophy.

Physical examination in the first week was consistently that of a flaccid infant in deep coma, being artificially ventilated. The anterior fontanel was scaphoid. Deep knee reflexes were brisk, and there was ankle clonus. He had bilateral inverted nipples. Laboratory evaluation revealed: $\mathrm{Na}$ 148, K4.8, $\mathrm{Cl} 108$ and $\mathrm{HCO}_{3} 23 \mathrm{mEq} / \mathrm{L}$; glucose 113, bilirubin 8.5; direct 0, BUN 26, creatine 1.2, calcium 8.8 and magnesium $1.7 \mathrm{mg} / \mathrm{dL}$. The $\mathrm{NH}_{3}$ was $37 \mu \mathrm{mol} / \mathrm{L}$. CK was $4025 \mathrm{u} / \mathrm{L}$.

Metabolic investigation revealed normal amino acids in plasma and CSF. The concentration of glycine was $214 \mu \mathrm{mol} / \mathrm{L}$ in plasma and $12 \mu \mathrm{mol} / \mathrm{L}$ in CSF. In plasma glutamine was 724 and alanine 343 $\mu \mathrm{mol} / \mathrm{L}$. Organic acid analysis of the urine was normal. Plasma total homocystine was 1.6. Qualitative dip stix test of the urine for sulfite was positive. Plasma concentration of uric acid on day 5 of life was $1.2 \mathrm{mg} /$ $\mathrm{dL}$, but 2 days later it was $0.3 \mathrm{mg} / \mathrm{dL}$. Urinary oxypurines were uric acid 0 , hypoxanthine 0.165 and xanthine $9.711 \mu \mathrm{mol} / \mathrm{mol}$ creatine (normal value $0.33-2.0,0.022$, and $0.020 .09 \mathrm{mmol} / \mathrm{mol}$ creatine respectively). The urinary sulfocysteine was $233 \mu \mathrm{mol} / \mathrm{g}$ creatine (normal <24).

He was weaned gradually from the ventilator and did well with oral feedings. He was discharged and seen as an outpatient where he thrived physically but showed no signs of development. He was responsive to light or sound and made no purposeful movements. Deep tendon reflexes were brisk and symmetrical. EEG remained abnormal with a generalized spike pattern, and he developed a seizure pattern of myoclonic or brief flexor spasms of the shoulders and trunk. Notable in the first year were overriding of the cranial sutures.

Mutations in the MOCS, gene were found at the Institute for Human Genetics by J. Reiss PhD: R67W (CGG>TGG in exon1 and G126D (GGT>GAT in exon 2, which had previously been described [1].

\section{Discussion}

The disease in this patient appeared to be incompatible with life. He displayed no neuro development, and he died in early infancy.

\section{Reference}

1. Reiss J, Johnson JL (2003) Mutations in the molybdenum cofactor biosynthetic genes MOCS1, MOCS2, and GEPH. Hum Mutat 21: 569-576. [Crossref]
Copyright: C2018 Nyhan WL. This is an open-access article distributed under the terms of the Creative Commons Attribution License, which permits unrestricted use, distribution, and reproduction in any medium, provided the original author and source are credited.
Correspondence to: William L. Nyhan, Professor, Department of Pediatrics, University of California, San Diego, USA, Tel: (619) 543-3580; Fax: (619) 5433565; E-mail: wnyhan@ucsd.edu

Received: March 03, 2018; Accepted: April 04, 2018; Published: April 10, 2018 